\title{
Growth curve of buffalo grazing on a grass pasture
}

\author{
Teresa Cristina Alves ${ }^{1}$, Raul Franzolin ${ }^{2}$
}

\author{
1 Embrapa Pecuária Sudeste, São Carlos, SP, Brasil. \\ 2 Universidade de São Paulo, Faculdade de Zootecnia e Engenharia de Alimentos, Departamento de Zootecnia, Pirassununga, SP, Brasil.
}

\begin{abstract}
The objective of this study was to evaluate the performance of 17 buffaloes (Mediterranean), from birth to slaughter age (720 days) with monthly measures of weight, thoracic perimeter, body length, and height at withers. At the end of experimental period, the animals were separated into two different groups for statistical analysis according to slaughter weight: light body weight (LBW, mean $517 \mathrm{~kg}$ ) and heavy body weight (HBW, mean $568 \mathrm{~kg}$ ). Buffalo growth occurs in the same way up to weaning age, and after that, two distinct groups grow in different forms in the same conditions of management and feeding. Body weight can be estimated according to age, thoracic perimeter, height, and length, showing high correlations. Buffaloes show growth in a sigmoid-curve model.
\end{abstract}

Key Words: body weight, growth, performance

\section{Introduction}

In Brazil, buffaloes are raised mainly for milk production. However, they also have a great potential for meat production, which can be used to increase the profits of farms.

Scientific advances are needed to improve buffalo production systems, including genetic improvement of herds. Studies on the animal body development are relevant in the selection of animals to optimize their weight gain by identifying the characteristics of the various factors that influence their growth performance, such as breed, gender, and nutrition (Grant and Helferich, 1991; Oliveira, 2005).

Body weight gain after weaning in buffalo represents the growth vigor of the animal, which is a substantial feature in the selection of animals (Moran, 1992). Therefore, body weight is the most commonly used criterion for assessing the growth of animals. However, the development of each animal is better measured when body weight is associated with measures of bone growth and body length. The height at withers reflects height growth (bone growth), while the body weight reflects also the growth of organs, muscle, and adipose tissue. The thoracic perimeter can be an alternative measure to estimate the body weight in animals. Several literature data report a high correlation

Received March 24, 2015 and accepted May 28, 2015.

Corresponding author: rfranzol@usp.br

http://dx.doi.org/10.1590/S1806-92902015000900003

Copyright (C) 2015 Sociedade Brasileira de Zootecnia. This is an Open Access article distributed under the terms of the Creative Commons Attribution License (http://creativecommons.org/licenses/by/4.0/), which permits unrestricted use, distribution, and reproduction in any medium, provided the original work is properly cited. between body weight and thoracic perimeter; however, these studies were developed with the Holstein cattle breed, and the data are not applicable to other breeds and other ruminant species, such as the bubaline (NRC, 2001).

Freitas (2005) evaluated the growth curve in eight species of domestic animals, but not buffalo, using seven nonlinear models, where the logistical model was identified as the most appropriate to measure the data of animal growth. In another study, the Logistic model was the best to describe the growth curve of buffaloes grazing on a tropical pasture in Cuba (Torres et al., 2009). The Logistic and Gompertz models were also recommended for growth curve in Murrah buffaloes (Araújo et al., 2012).

The aim of this trial was to determine the growth curve in buffaloes, studying the correlation among body weight, age, body length, thoracic perimeter, and height at withers in male buffaloes raised exclusively on a tropical grass during 720 days, allocated to two groups according to the final slaughter body weights.

\section{Material and Methods}

The experiment was conducted in Pirassununga, São Paulo State, Brazil, according to proceedings approved by the Animal Research Ethics Committee. During 720 days, measurements of body weight, thoracic perimeter, height at withers, and body length were taken every 28 days in 17 male buffaloes of the Mediterranean breed born between March and May, from birth to slaughter weight, generating a total of 1,700 data. At the end, the animals were separated into two groups according to slaughter weight for the statistical analysis of the evaluated parameters, constituting 
two treatments: low body weight (LBW), with nine animals and $517 \mathrm{~kg}$ of average slaughter weight; and high body weight (HBW), with eight animals and $568 \mathrm{~kg}$ of average slaughter weight.

The female buffaloes were exploited for milk production in which they were milked once daily, beginning at around $07.00 \mathrm{~h}$. The herd consisted of animals of low milk production (mean $4.4 \mathrm{~kg}$ of milk/animal/day). During the first 20 days of milking, one teat of the udder was reserved for calf sucking. Immediately after each milking session, the calves remained with their mothers on a tropical grass pasture, Brachiaria brizantha cv. Marandu, at up to $13.00 \mathrm{~h}$, and then kept inside facilities for calves. The calves' housing was an indoor collective facility, with concrete floor and solarium paddock with the same grass. All calves received feed supplementation with grass hay (ad libitum), and as the group of calves was homogeneous, the supplementation concentrate was provided in a fixed amount of $0.3 \mathrm{~kg} /$ animal/day until weaning.

After weaning, the calves (7-8 months age) were maintained on pasture, supplemented with corn silage $(6 \mathrm{~kg} /$ animal $/$ day $)$ and concentrate $(0.6 \mathrm{~kg} / \mathrm{animal} /$ day $)$ during the first month. In the second month, the animals received only concentrate supplementation, and from the third month they were put on grazing with a mineral supplement containing the following elements $(\mathrm{g} / \mathrm{kg}$ of total mix): $\mathrm{P}$ (85 g), Ca (130 g), magnesium (5 g), S (25 g), Na (156 g), $\mathrm{Cl}$ (240 g), Zn (5,000 mg), Cu (1,500 mg), Fe (1,700 mg), Mn (1,250 mg), Co (120 mg), I (120 mg), Se (15 mg), and $\mathrm{Fl}$ (maximum $850 \mathrm{mg}$ ). All the animals were castrated upon weaning.

The animals were weighed on a calibrated livestock scale. The thoracic perimeter was measured with a measuring tape placed just behind the hind limbs, making up the circumference around the chest with the animal positioned properly. The height at withers was measured with an adjustable ruler placed next to forelimbs just ahead of the defined location for measuring the thoracic perimeter. The body length was measured using a tape measure in a straight line between the scapularhumeral joint and the thigh tuberosity of the ileum. All measurements were adjusted to 30-day intervals according to the following equation: $\operatorname{AdjM}=\operatorname{PrM}+\left(\mathrm{ADGW}^{*} 30\right)$, in which: $\operatorname{Adj} M=$ adjusted measure; $\operatorname{Pr} M=$ previous measure; $\mathrm{ADGw}=$ average daily gain in body weight.

The PROC GLIMMIX procedure of SAS (Statistical Analysis System, version 9.3) was used for comparison of means, and the statistical model included covariates like animal's date of birth, category, and age (adjusted data). In addition, the measures of body weight $(\mathrm{kg})$ and age (days) of the animals were adjusted to nonlinear Logistic models using statistical software (Statsoft 2013, version 12): $\mathrm{y}=\mathrm{A}\left(1+\mathrm{e}^{-\mathrm{Kt}}\right)^{-\mathrm{M}}+\varepsilon$, in which $\mathrm{y}=$ weight of the animal at an age (t); $\mathrm{A}=$ asymptotic value of yt (average maturity weight); $\mathrm{K}=$ rate of change of the exponential function (maturation rate, referring to the relative growth rate until reaching the mature weight); $\mathrm{M}=$ the parameter that shapes the curve; $\mathrm{e}=$ the natural logarithm base; and $\varepsilon=$ the random error associated with each weighing. This model was chosen because it was reported as the best model to describe growth in animal (Freitas, 2005) and buffalo production (Araújo et al., 2012).

\section{Results and Discussion}

The average body weights obtained from birth to slaughter in both groups (LBW and HDW) showed excellent buffalo performance on an extensive grazing system (Table 1) compared with other investigations with buffaloes raised on tropical grasslands in Brazil (Nogueira et al., 2000; Jorge et al., 2005; Malhado et al., 2008), confirming the wide variation in the potential of buffalo to gain weight according to the animal genetic potential, management system technique, forage potential, milk production, etc. No differences $(\mathrm{P}<0.05)$ were observed between groups of animals in body weight, age, body length, thoracic perimeter, or height at withers at birth, demonstrating the homogeneity of all animals at the beginning of the experiment.

According to Nogueira et al. (2000), buffalo calves with a higher birth weight often tend to gain weight faster before and after weaning. The animals in HBW showed less weight variation (standard deviation) than LBW, characterizing the group as more homogeneous in all weightings.

Both buffalo groups began to differentiate in body weight at weaning age (210 days) (Figure 1). According to Moran (1992), weight gain after weaning demonstrates the vigor of animal growth, representing a striking feature

Table 1 - Body weight ( \pm standard deviation) of two buffalo groups grazing on a tropical grass in different ages

\begin{tabular}{lccc}
\hline \multirow{2}{*}{ Age (days) } & \multicolumn{2}{c}{ Weight $(\mathrm{kg})$} & \multirow{2}{*}{ P-value } \\
\cline { 2 - 3 } & LBW & HBW & \\
\hline Birth & $45.8 \pm 5.50$ & $43.5 \pm 1.69$ & 0.2793 \\
210 & $205.7 \pm 23.35$ & $223.4 \pm 12.89$ & 0.0770 \\
360 & $312.9 \pm 17.41$ & $340.5 \pm 10.86$ & 0.0015 \\
540 & $380.4 \pm 19.70$ & $418.9 \pm 17.64$ & 0.0008 \\
720 & $519.3 \pm 21.24$ & $559.8 \pm 12.28$ & 0.0003 \\
\hline
\end{tabular}

LBW - light body weight; HBW - heavy body weight. 
in the animals' selection process. Therefore, after weaning, animals can be separated into categories with propensity to more or less body weight gain, which is an important feature for selection of breeding or fattening management groups.

Significant differences were observed between the two animal groups after 180 days of age in height at withers (Figure 2), 210 age days in body length (Figure 3), and 270 age days in thoracic perimeter (Figure 4). In this last parameter, greater chest expansion was indicated in heavier animals. In general, both groups grew in the same way while in the nursing period. Therefore, the growth curve had a different model for each category (HBW and LBW) with only few exceptions.

The body weight data had a higher correlation with the animals' age regardless of the categories (HBW, LBW, and total) when adjusted with the Logistic model (Table 2). The biological interpretation of the curve shows that the large values of $\mathrm{K}$ indicate early maturity, while small $\mathrm{K}$ values represent the late maturity of the animal. Genetic and environmental factors influence the body weight-age curve or the asymptotic weight (A). The inflection point of the curve was determined according to the slope (M) (Brown et al., 1976) as $239.8 \mathrm{~kg}$ for LBW group, $249.3 \mathrm{~kg}$ for HBW, and $244.0 \mathrm{~kg}$ for all animals. The inflexion is the changing point on the growth rate that is characterized by decreasing development growth. The weight changing rate is maximum at the inflexion point. The age estimates by non-linear equation for LBW, HBW, and for total animals showed inflection points at 242, 256, and 248 days, respectively. The average mature weight (A) of $578.4 \mathrm{~kg}$ (Table 2) was higher than that observed by Araújo et al. (2012) with Murrah buffaloes also adjusted to $428.8 \mathrm{~kg}$ by the Logistic model. However, the animals showed lower values for $\mathrm{K}=0.0069$ and $\mathrm{M}=4.089$, and also a higher maturity weight than that observed with growing buffalo females in Cuba, $\mathrm{A}=546.3$ (Torres et al., 2009). The lower maturity rate observed can be related to a greater maturity weight.

The weight-age curve obtained is the sigmoid type (Figure 5), in which the A value provides an indication of the weight at which the animal reaches maturity,

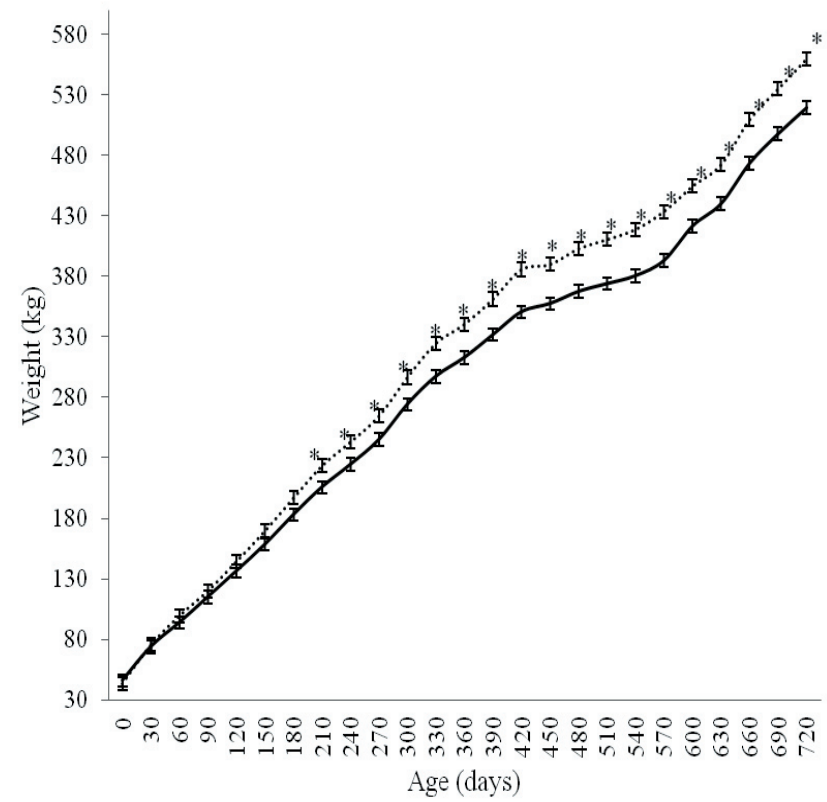

LBW - light body weight (full line); HBW - heavy body weight (dotted line) $*$ Different values $(\mathrm{P}<0.05)$.

Figure 1 - Growth curve of weight vs age of two buffalo groups grazing on a tropical grass.

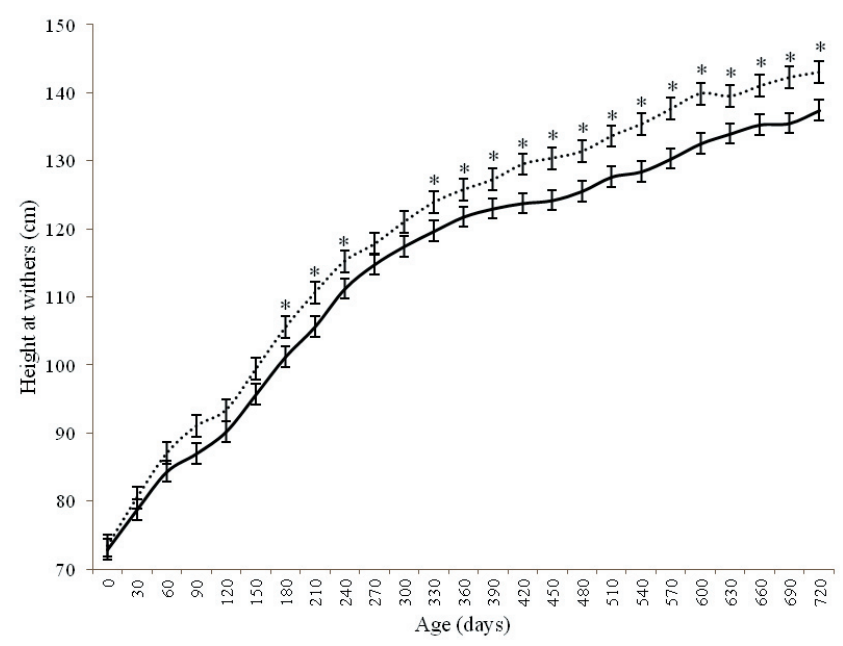

LBW - light body weight (full line); HBW - heavy body weight (dotted line); *Different values $(\mathrm{P}<0.05)$.

Figure 2 - Growth curve of height at withers vs. age of two buffalo groups grazing on a tropical grass.

Table 2 - Characteristics of the Logistic model, $\mathrm{y}=\mathrm{A}\left(1+\mathrm{e}^{-\mathrm{Kt}}\right)^{-\mathrm{M}}$, in the growth performance $(\mathrm{kg})$ of buffalo from birth to 720 days grazing on a tropical grass

\begin{tabular}{lcccc}
\hline & $\mathrm{A}(\mathrm{kg})$ & $\mathrm{K}(\mathrm{kg} /$ day $)$ & $\mathrm{M}$ & $\mathrm{R}$ \\
LBW & $567.90 \pm 14.2$ & $0.0040 \pm 0.00016$ & $2.976 \pm 0.053$ & 6 \\
HBW & $591.77 \pm 10.5$ & $0.0043 \pm 0.00014$ & $3.037 \pm 0.048$ & 0.984 \\
Overall & $578.38 \pm 10.2$ & $0.0042 \pm 0.00013$ & $3.003 \pm 0.042$ & 0.991 \\
\hline
\end{tabular}

LBW - light body weight; HBW - heavy body weight. 
and was similar to that obtained in sheep performance with the Von Bertalanffy model (Freitas, 2005). In cattle, Brody (1945) established the growth curve as sigmoid type with two distinct phases. In the first phase, growth is accelerated until puberty, predominantly bone growth and muscle tissue stimulated by the release of growth hormone. In the second phase, after puberty, growth is slowed due to increased action of steroid hormones that increase the deposition of adipose tissue (Grant and Helferich, 1991). These data also corroborate Owens et al. (1993), who showed that weight in relation to age is a sigmoid curve, in which the gain is accelerated until puberty, and the inflection point can be observed, and then the gain becomes slower until maturity.

The buffaloes had good weight gain, with differences in the evaluated growth periods (Table 3). The daily weight gain was higher in heavy animals from birth to weaning $(\mathrm{P}<0.036)$, with an improvement in performance

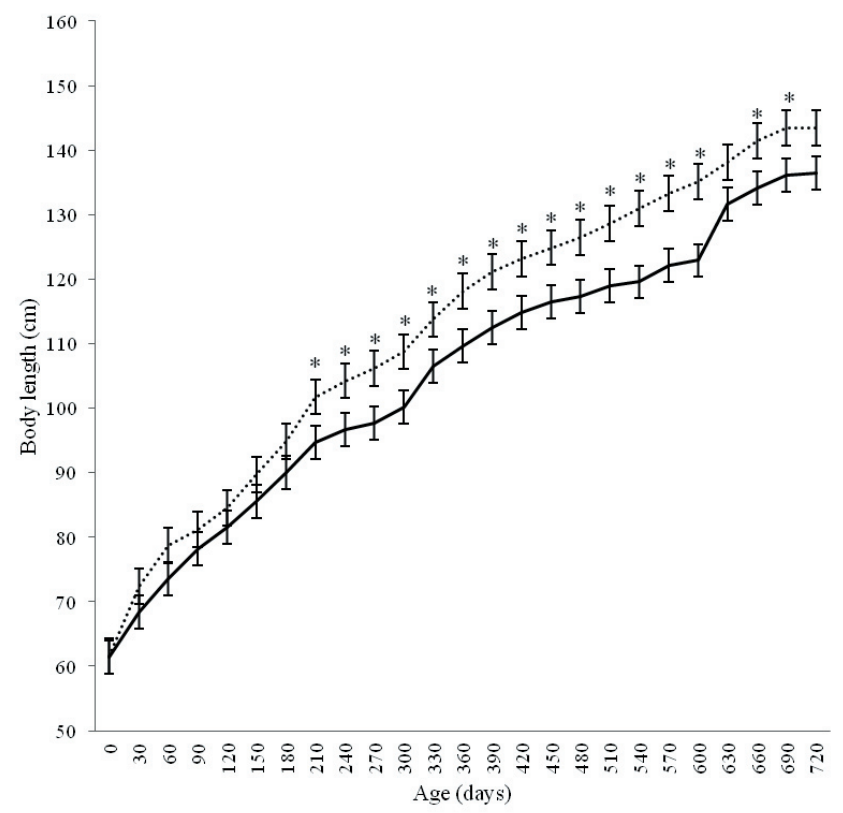

LBW - light body weight (full line); HBW - heavy body weight (dotted line); *Different values $(\mathrm{P}<0.05)$.

Figure 3 - Growth curve of body length vs. age of two buffalo groups grazing on a tropical grass.

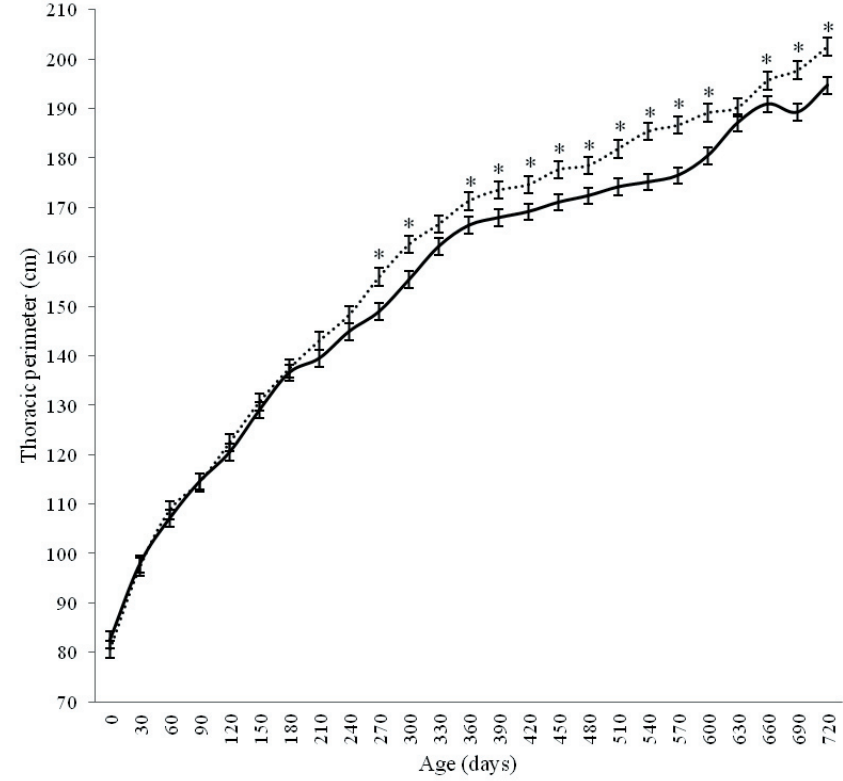

LBW - light body weight (full line); HBW - heavy body weight (dotted line); *Different values $(\mathrm{P}<0.05)$.

Figure 4 - Growth curve of thoracic perimeter vs. age of two buffalo groups grazing on a tropical grass.

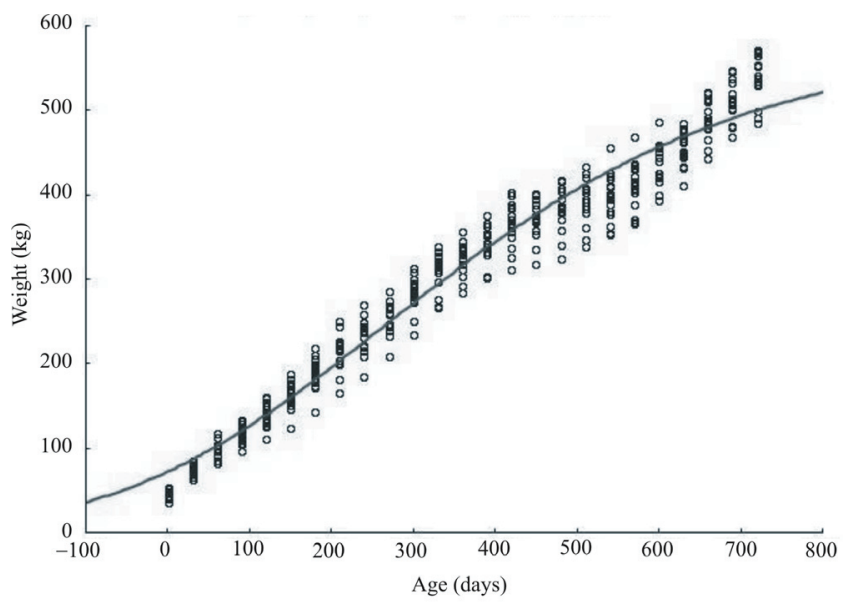

$\mathrm{y}=578.397 *\left(1+\mathrm{e}^{-0.004171 x}\right)^{-3.0034} ; \mathrm{R}^{2}=0.9662$

Figure 5 - Growth curve of weight vs. age of buffalo grazing on a tropical grass from birth to 720 days adjusted to a logistic nonlinear model.

Table 3 - Average daily body weight gain ( $\mathrm{kg} \pm$ standard deviation) of two buffalo groups grazing in different periods of growth

\begin{tabular}{lcccc}
\hline \multirow{2}{*}{ Age (days) } & \multicolumn{2}{c}{ Group } & P-value & Mean \\
\cline { 2 - 4 } & LWB & HWB & 0.036 & $0.806 \pm 0.10$ \\
\hline Birth to 210 & $0.761 \pm 0.10$ & $0.856 \pm 0.06$ & 0.073 & $0.746 \pm 0.07$ \\
210 to 360 & $0.715 \pm 0.06$ & $0.480 \pm 0.08$ & 0.187 & $0.404 \pm 0.10$ \\
360 to 540 & $0.375 \pm 0.08$ & $0.782 \pm 0.11$ & 0.831 & $0.777 \pm 0.09$ \\
540 to 720 & $0.773 \pm 0.06$ & & 0.11 \\
\hline
\end{tabular}

LBW - light body weight; HBW - heavy body weight. 
A)
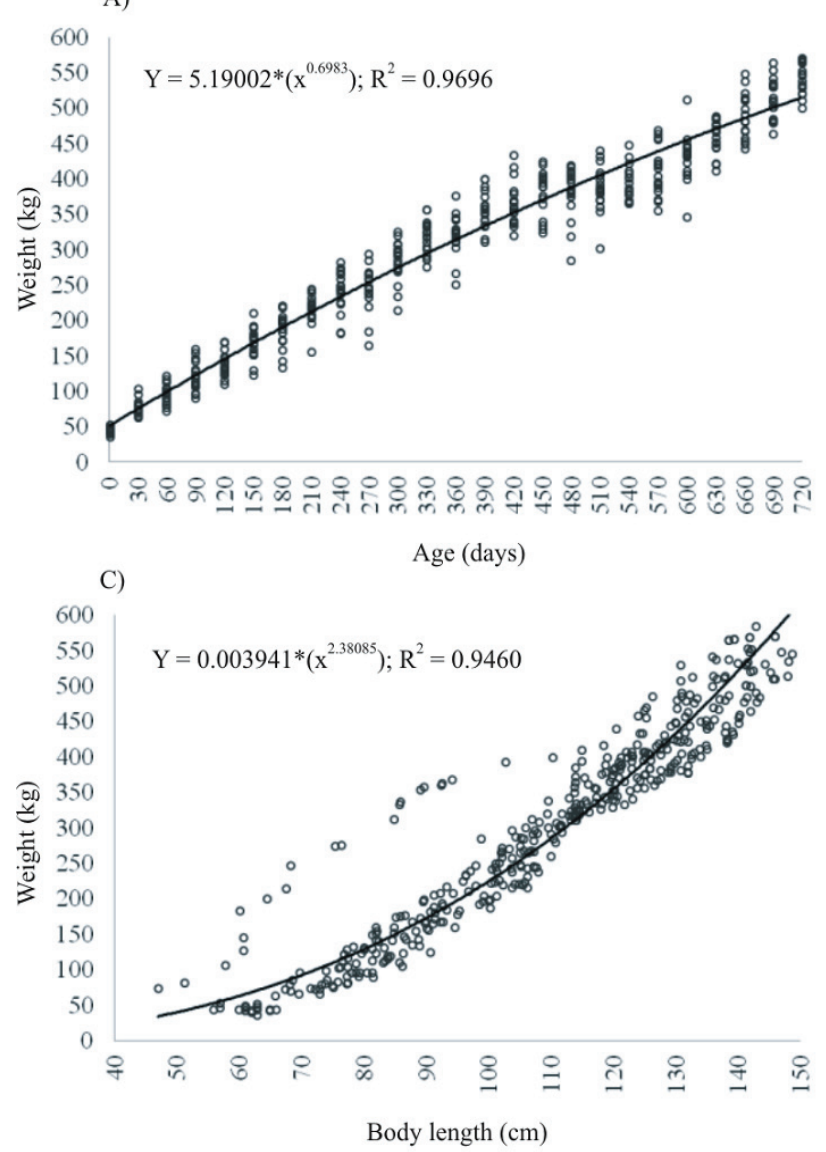

B)

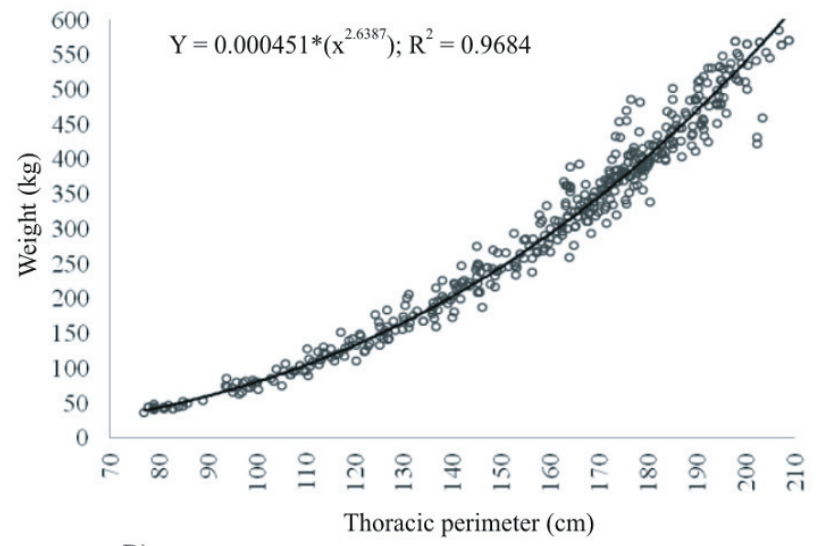

D)

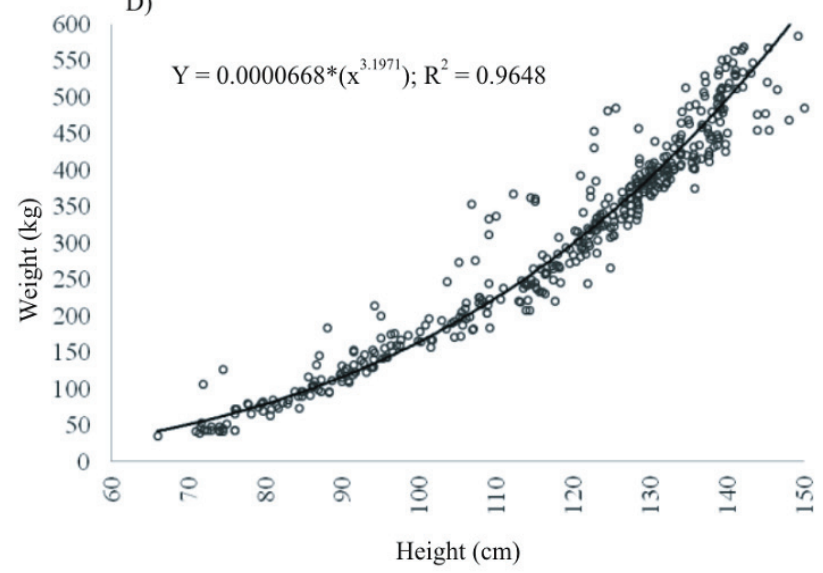

Figure 6 - Growth curves of buffalo in nonlinear models plotted by body weight vs. age (A), thoracic perimeter (B), body length (C) and height at withers (D).

of $12.5 \%$ in heavy animals $(0.856 \mathrm{~kg} / \mathrm{day})$ compared with light animals $(0.761 \mathrm{~kg} /$ day $)$, and from weaning to weight of 360 days age $(\mathrm{P}<0.073)$, reflecting the higher growth momentum of animals during the first year of life. After one year of age, no significant differences were observed due to a dry period, with a low weight gain (mean $0.404 \mathrm{~kg} /$ day) up to 540 days, and thereafter at the final stage, with a steeper gain (mean $0.777 \mathrm{~kg} /$ day). Thus, the effects of environment and management are directly related to the growth of buffalo in the same conditions, differentiating groups of different animals within the same herd.

The nonlinear regressions for the estimate of weight $(\mathrm{kg})$ in relation to age (days), thoracic perimeter $(\mathrm{cm})$, body length $(\mathrm{cm})$, and height at withers $(\mathrm{cm})$ were highly significant $\left(\mathrm{P}<0.01 ; \mathrm{R}^{2}=0.95\right.$ to 0.97 ; Figure 6$)$. The best correlation was between body weight and thoracic perimeter $\left(\mathrm{R}^{2}=0.9684\right)$. Thus, body weight in buffaloes can be estimated with measurements of thoracic perimeter in places with difficult access for the scale, using the following equation: $\mathrm{y}=0.000451\left(\mathrm{x}^{2.6387}\right)$, in which $\mathrm{y}=$ weight $(\mathrm{kg})$ and $\mathrm{x}=$ thoracic perimeter $(\mathrm{cm})$.

\section{Conclusions}

Male Mediterranean buffaloes grazing on tropical grasslands show the same growth body weight curves from birth to weaning age (around 210 days), but after that, there is a greater differentiation in the growth until slaughter weight $(720 \mathrm{~kg})$ in animals raised in the same condition within the same herd. Measures of thoracic perimeter, age and height at withers can be used to estimate the body weight of buffalo. Buffalo show growth in a sigmoid-curve model.

\section{Acknowledgments}

We thank Coordenação de Aperfeiçoamento de Pessoal de Nível Superior (CAPES) for the financial support (Doctoral grant). 


\section{References}

Araújo, R. O.; Marcondes, C. R.; Damé, M. C. F.; Garnero, A. D.; Gunski, R. J.; Everling, D. M. and Rorato, P. R. N. 2012. Classical nonlinear models to describe the growth curve for Murrah buffalo breed. Ciência Rural 42:520-525.

Brody, S. 1945. Bioenergetics and growth. Reinhold, New York.

Brown, J. E.; Fitzhugh, H. A. and Cartwright, T. C. 1976. Comparison of nonlinear models for describing weight-age relationships in cattle. Journal of Animal Science 42:810-818.

Freitas, A. R. 2005. Curvas de crescimento na produção animal. Revista Brasileira de Zootecnia 34:768-795.

Grant, A. L. and Helferich, W. G. 1991. An overview of growth. p.1-16. In: Growth regulation in farm animals. Advances in meat research. v. 7. Pearson, A. M. and Dutson, T. R., eds. Elsevier Applied Science, New York.

Jorge, A. M.; Andrighetto, C. and Castro, V. S. 2005. Desenvolvimento ponderal de bubalinos da raça Murrah criados em pastagem de Brachiaria brizantha no centro-oeste do Estado de São Paulo, Brasil. Ciência Rural 35:417-421.

Malhado, C. H. M.; Ramos, A. A.; Carneiro, P. L. S.; Souza, J. C.; Wechsler, F. S.; Eler, J. P.; Azevêdo, D. M. M. R. and
Sereno, J. R. B. 2008. Modelos no lineales para describir el crecimiento de bufalinos de la raza Murrah. Archivos de Zootecnia 57:497-503.

Moran, J. B. 1992. Growth and development of buffaloes. p.199-221. In: Buffalo production. Tulloch, D. and Holmes, C. W., eds. Australia.

NRC - National Research Council. 2001. Nutrient requirements of dairy cattle. 7th ed. National Academy Press, Washington, D.C.

Nogueira, J. R. N.; Lima, M. L. P.; Soares, W. V. B. and Gadini, C. H. 2000. Curva de crescimento de bubalinos Mediterrâneo no noroeste do estado de São Paulo. Boletim de Industria Animal 27:163-169.

Oliveira, A. L. 2005. Búfalos: Produção, qualidade de carcaça e de carne. Alguns aspectos quantitativos, qualitativos e nutricionais para promoção do melhoramento genético. Revista Brasileira de Reprodução Animal 29:122-134.

Owens, F. N.; Bubeski, P. and Hanson, C. F. 1993. Factors that alter the growth and development of ruminants. Journal of Animal Science 71:3138-3150.

Torres, V.; Sampaio, I. and Fundora, O. 2009. Stochastic model of the productive performance in the growing stage of water buffaloes in Cuba. Cuban Journal of Agricultural Science 43:111-114. 